\title{
Sadayakko és Hanako Budapesten
}

Kawakami Sadayakko 川上貞奴 (1871-1946) és Ōta Hisa, müvésznevén Hanako 花子 (1868-1945), a XIX-XX. század fordulójának fontos színháztörténeti alakjai. A két színésznő európai és amerikai fellépéseinek köszönhetően hatással volt a nyugati színház- és művészvilág olyan alakjaira, mint Edward G. Craig, Mejerhold, Puccini, Picasso vagy Rodin.

Sadayakko, aki gésaelőélettel rendelkezett, férje, Kawakami Otojirō 川上 音二郎 (1864-1911) társulatával utazott először az Egyesült Államokba 1899-ben, és vált a társulat vezető színésznőjévé akkor, amikor Japánban még csak néhány éve engedélyezték újra a nők színpadon való megjelenését. ${ }^{1} \mathrm{~A}$ társulat és Sadayakko sikereit jelzik, hogy az 1900-as párizsi világkiállításon már sztárként ünnepelték a japán színésznőt. A korabeli közönség elképzelései ellenére azonban a bemutatott darabok egyáltalán nem voltak autentikusak, valójában Kawakami Otojirōnak ${ }^{2}$ kedvenc kabukidarabjaiból láthatott a közönség különbözö, a nyugati dramaturgiához igazított (romantikus, táncos, illetve harcos jelenetekkel dúsított) ,egyvelegeket”, amelyek közül a legsikeresebb $A$ gésa és a lovag ${ }^{3}$ volt, Sadayakkóval a főszerepben. Ezt az előadást láthatta az európai közönség a legtöbbször a társulat 1901 és 1902 között zajló turnéján is.

Hanako, hasonlóan Sadayakkóhoz, szintén rendelkezett gésamúlttal, illetve gyerekszínészi pályafutással, ő már egy kis japán társulat színésznőjeként járta Európát, mikor 1905-ben Loïe Fuller (1862-1928) felfedezte. Ettől a pillanattól kezdve Hanako karrierje szorosan összekapcsolódott a táncosnőjével, ő írt

1 Kawakami Sadayakko életéről és nyugati turnéiról, illetve japán színházi munkásságáról bővebben magyar nyelven: Doma 2013: 74-87; angolul föként: Kano 2001 és Downer 2003.

2 Kawakami Otojirō életéről és munkásságáról, a seigeki kidolgozásáról bővebben magyar nyelven: Doma 2019: 239-258; angolul föként Anderson 2011.

3 A történet Katsuragi gésa reménytelen szerelméről szól, akit elhagy szamuráj kedvese korábbi menyasszonyáért. A gésa ugyan megpróbálja visszaszerezni szerelmét, de az előadás végére beleőrül a fájdalmába, és meghal. 
neki különböző japanizáló előadásokat, és ő szervezte fellépéseit Európaszerte éveken át. ${ }^{4}$

Összességében elmondható, hogy mindkét színésznő alapvetően haláljeleneteikkel kápráztatta el a közönséget. Mind Kawakami Otojirōnak a nyugati ízléshez igazított kabuki előadásai, mind a Loïe Fuller által írt japanizáló produkciók a főhősnők látványos és már-már túlzóan realisztikus halálával értek véget. Tehát a produkciók egyszerre kínálták az idegen és a vágyott egzotikum megmutatását, továbbá egy borzongatóan naturalista halált.

Európai körútjuk során Kawakami Sadayakko és Hanako is járt az OsztrákMagyar Monarchia területén, több magyar település mellett mindketten felléptek Budapesten is. Szereplésük alapvetően sikeresnek volt mondható, és számos esetben hasonló visszhangra találtak, mint más európai országok sajtóorgánumaiban. Emellett azonban - föként Hanako esetében - kritika is érte őket, amely előadásaik autentikusságát kérdőjelezte meg. Ezáltal budapesti vendégjátékaik fontos részét képezik recepciójuknak, lényegesen tovább árnyalják a közönségnek a produkciókról kialakított képét, illetve érdekes adalékokkal gazdagítják a korabeli magyar színháztörténetet is.

\section{Japán megjelenése a magyar köztudatban}

Magyarország az Osztrák-Magyar Monarchia részeként politikai és kereskedelmi szempontból a XIX. század második felében kezdett érdeklődni Japán iránt. Az 1869-es hivatalos diplomáciai kapcsolatfelvételre ${ }^{5}$ a magyar kormány részéről öt föt delegáltak, ${ }^{6}$ köztük Xantus János földrajztudóst, aki számos értéktárggyal érkezett haza, s gyüjtéséből már 1871-ben kiállítást szerveztek. Valódi politikai figyelmet azonban csak 1902, vagyis az angol-japán szövetség megkötése után szenteltek az országnak, mivel ez a szerződés már sejtetni

4 Hanako karrierjéről, Loïe Fullerrel való együttmüködéséről és Rodinnel való kapcsolatáról bővebben magyar nyelven: Doma 2017: 95-105; angolul és japánul főként: Savarese-Flower 1988: 63-75 és Sawada 1996.

5 A kapcsolatfelvételről és a kereskedelmi szerződésről ld. bővebben: Szerdahelyi 2009: 27-43.

6 A Japánba küldött két hajón tartózkodott Kaas Ivor publicista, Cserei Mór újságíró, Bernáth Géza és Hengelmüller László diplomaták, valamint Xantus János. Vö.: Tóth 2018: 39. 
kezdte Japán nagyhatalmi sorba emelkedését, amelyet végül az orosz-japán (1904-1905) háborúban aratott győzelem igazolt.?

Magyarországnak azonban a hivatalos kapcsolatfelvétel előtti időkből is voltak már ismeretei Japánról. Feltételezhető, hogy az első magyar utazó Ureman János volt, aki jezsuita hittérítőként élt Edóban 1608 és 1614 között. Japánban és más kelet-ázsiai országokban szerzett tapasztalatait azonban csak 1722-ben adták ki Itinerarium peregrini philosophi (Egy vándor filozófus útinaplója) címmel. ${ }^{8}$ A XVIII. század második felétől egyre több - főként földrajzi - információ ért el Magyarországra, elsősorban a keresztény misszionáriusokon, valamint a portugál és holland kereskedőkön keresztül. A XIX. századtól az ismeretterjesztés már a gazdasági, társadalmi és kulturális életre is kiterjedt, ilyen volt például 1869-ben a Budapesti Szemlében Hunfalvy János cikksorozata, amely külföldi, Japánt megjárt szakértők munkáinak fordításán alapultak. ${ }^{9}$ A Meiji-megújulást követően pedig föként a Vasárnapi Ujság írt előszeretettel Japánról a legkülönbözőbb témákban.

1869 után Széchenyi Béla volt az első, aki hosszabb keleti expedícióra vállalkozott, ezt követte a Monarchia újabb hivatalos kelet-ázsiai látogatása 1890 és 1892 között, majd Ferenc Ferdinánd 1893-ban tett Föld körüli útja egyik állomásaként is ellátogatott Japánba. Természetesen mindegyik útról készültek beszámolók, ${ }^{10}$ amelyek tovább növelték a magyar közönség érdeklődését. Az 1889-től induló rendszeres, személyszállító hajójáratok indítása pedig lehetővé tette, hogy civil utasok is eljussanak a szigetekre. „Az utazás e csodaországba ma már a nagy expedítiók közé nem tartozik. A kinek pénze, ép egészsége van, és vértezett a zaklató tengeri betegség ellen, az könnyen vállalkozhatik arra." 11

A századfordulóra az utazók egyre növekvő száma magával hozta a jelentős mennyiségü és népszerü cikkek, tanulmányok, úti naplók és beszámolók meg-

\footnotetext{
7 A háborúval kapcsolatos magyar benyomásokról ld.: Szerdahelyi 1996 és Doma 2011.

8 Bögös 1991.

9 Vö. Farkas 2009: 67.

10 Széchenyi útjáról szól a Gróf Széchenyi Béla keleti utazásai (1882) című mű, míg a Monarchia útjáról Gáspár Ferenc hajóorvos, a trónörökös látogatásáról Reményi Ferenc sorhajóhadnagy beszámolóit, illetve a Vasárnapi Ujság vontkozó számait (1894. február 25. és március 4.) olvashatták az érdeklődők.

11 Majláth Géza 1892. „A japáni szigetvilágon keresztül.” Földrajzi közlemények, 171172. - idézi: Tóth 2018: 72.
} 
jelenését is. Talán a két legnépszerübb ezek közöl Bozóky Dezső (1871-1957) ${ }^{12}$ Két év Keletázsiában (sic!) és Baráthosi Balogh Benedek (1870-1945) ${ }^{13}$ Japán, a Felkelö Nap országa címü kötete. A legtöbb utazó - amellett, hogy szerették volna megosztani élményeiket - kifejezetten alkalmasnak találta a keleti témát az egyéniség és egyediség kifejezésére. Számos amatôr írót, publicistát pontosan ugyanaz a vágy hajtott, mint a romantika korának alkotóit, akik szintén a szabadság eszményét, a miszticizmust és a szerelem újfajta világát vélték felfedezni „Keleten”. ${ }^{14}$

„Az eredeti benyomását keltette minden keleties munka, mert eddig még soha el nem ismételt színeket és keretet hozott. Legtöbbször a Keletnek éppen az ismeretlensége keltette az eredetiség hatását, mert minden ismeretlen, még ha hazug színekkel festik is, különösnek és érdekesnek tetszik előttünk."

Az egyre hitelesebb - néha negatív véleményt is megfogalmazó - beszámolók és előadások ellenére a XX. század elején a legtöbb magyar számára Japán még mindig „elbűvölő tündérország” volt, ${ }^{16}$ amely elképzelést a világkiállítások, a hazai tárlatok és a japonizmus hazai térhódítása is megerősítette.

Általánosan elmondható, hogy a magyar közönség pozitívan reagált az újdonságokra: ,a japánok nagyon kedvező szinben tünnek fel elöttünk, a mióta oly sietve, oly csodálatos ügyességgel vették át az európai civilizáció vívmányait". ${ }^{17}$ Az idézett cikk szerzője még arra is kitér, hogy a kelet-ázsiai népek közül a Japán a legtiszteletreméltóbb, mivel átvették az európai szokásokat, és az ilyen nép „kultúrára fogékony” és „tehetséges”. ${ }^{18}$ A XIX. század végén a japán kormány által szorgalmazott „megfelelés” az európai országoknak tehát sikeresnek volt mondható magyar vonatkozásban is, ahol persze ugyanúgy megfigyelhető a korszakra jellemző „nyugati gőg és felsőbbren-

12 Dr. Bozóky Dezső sorhajóorvos, 1907-1909 között járt Kelet-Ázsiában. Élményeit részletes leírásokkal, saját és vásárolt fényképekkel gazdagított kétkötetes müvében jelentette meg 1911-ben. A témáról bővebben: Dénes-Sebestyén 2016: 11-34. Baráthosi Balogh Benedek néprajzkutató 1903 és 1921 között több alkalommal járt Japánban. Másik jelentős háromkötetes műve az országról a Dai Nippon, amely 1906-ban jelent meg.

Staud 1999.

Uo.

Tóth 2018: 87.

„A japánok.” 1904. március 6. Vasárnapi Ujság.

Uo. 
dűség”. Azért is volt elengedhetetlen Japán szereplése a világkiállításokon, mert az információszerzésen túl itt tudta megmutatni magát és növelni saját presztízsét Európa szemében. A hazai közönség számára a legelérhetőbb ezek közül az 1873-as bécsi világkiállítás volt, amely Japán szempontjából is jelentős eseménynek számított, mivel ez volt az első olyan kiállítás és nemzetközi szereplés, amelyen már a Meiji-megújulást követően vettek részt, és saját magukat reprezentálták, szemben az 1867-es világkiállítással, ahol még a kiállított anyagok európai diplomaták válogatásának eredményei voltak. ${ }^{19}$ A 70 főből álló delegáció egy több mint 6000 darabos kollekcióval érkezett a Monarchia fővárosába, ahol elsősorban a nyugati elvárásokhoz igazodva főként hagyományos textil- és kerámiaipari termékeket mutattak be. Voltak azonban ukiyo-e festmények, iparművészeti tárgyak, tradicionális hang- és játékszerek, valamint legyezők is, amelyeket jelentős mennyiségben áruba is bocsátottak. ${ }^{20}$

A rendkívül nagy népszerüségnek köszönhetően a századfordulóra egyre több japán témájú kiállítás nyílt Magyarország területén, amelyeken az érdeklődők többek között a Japánt megjárt két neves gyüjtő Hopp Ferenc (1833-1919) és gróf Vay Péter (1863-1948) műkincseit is megcsodálhatták. A művészek közül Rippl-Rónai József számított a japonizmus fő népszerúsítójének, 1900-ban egy nyilvános kiállítás keretében mutatta be kínai és japán gyüjteményét. ${ }^{21} \mathrm{Az}$ első kifejezetten japánfametszet-kiállításokat azonban csak 1908-ban, illetve 1910-ben rendezték meg a Szépmüvészeti Múzeumban, és ezt követte a korszak legjelentősebb tárlata, amelyet 1911-ben az Iparmüvészeti Múzeumban tekinthettek meg az érdeklődők. Bár a rendezvény címe „tartalmazta az »iparmüvészeti« kifejezést, a kollekció képző- és iparművészeti tárgyakat egyaránt tartalmazott". ${ }^{22}$

Magyarországon alapvetően a nyugat-európaitól eltérő japonizmus figyelhető meg mind a stílus, mind a témák és a motívumok szintjén, ${ }^{23} \mathrm{~s}$ a század-

\footnotetext{
Dénes 2017a: 127.

Tóth 2018: 165-167.

Gellér 2017: 23.

Dénes 2017a: 161.
}

23 Ezt a véleményt föként Gellér Katalin képviseli, míg Dénes Mirjam szerint erről csak egy részletes, régiókat összehasonlító vizsgálat után lehetne beszélni. „,[A]z OsztrákMagyar Monarchia teljes területét többé vagy kevésbé érintenie kellett a jelenségnek, és az lenne igazán érdekes, ha ezeket a régiós átmeneteket lehetne szépen lekövetni. Azt, hogy a közép-európai japonizmus más volt-e a nyugat-európai országokétól, és ha igen, akkor miben különbözött tőle, csak a teljes régió feltérképezése után lehetne megválaszolni” Dénes 2017b. 
forduló után mindez beépült a szecesszióba. Ez elsősorban annak volt köszönhető, hogy a japán müvészeti hatás először angol, francia, valamint német művészek munkáin keresztül érkezett hazánkba. „A müvészek többsége már kiérlelt életművek integráns részeként, más törekvésekkel összefonódva ismerte meg, közvetett vagy közvetlen hatása azonban mégsem tekinthető elhanyagolhatónak." ${ }^{24}$ Sőt a japonizmus elterjedése után egyfajta regionális sajátosság is megfigyelhető: ,[a] legjelentősebb eltérést a nyugati orientalizmustól a magyarság keleti származásának tudata idézte elő, amely a magyar közösséget erősen diszponálta a keletieskedés befogadására". ${ }^{25}$ Így ez a párhuzam is segíthette - az általános egzotikum iránti kíváncsiság mellett - a japonizmus, illetve minden japanizáló tárgy, termék, esemény, irodalom ${ }^{26}$ lelkes fogadtatását, többek között az első japán témájú színházi előadásokét is.

\section{Japanizáló előadások Magyarországon}

Az első - kevésbé ismert - japán témájú előadást, a Kozikit 1877. április 27-én mutatták be a Népszínházban. Alexandre Charles Lecocq zenéje mellett William Busnach és Armand Liorat szövegét Rákosi Jenő dolgozta át. ${ }^{27}$ A történetről - amely Japánban játszódik, és egy hatalommegszerzési kísérletet mutat be a csecsemő trónörökös elrablásával és egy kislány csecsemő általi helyettesítésével - a Vasárnapi Ujság adott beszámolót:

„Japáni történet, sok bohósággal, s néhány félremagyarázhatatlan kétértelmüséggel. Koziki mint japáni trónörökös van nevelve, el is foglalja a trónt és meg is házasodik, mikor kiderül, hogy voltaképen nem is trónörökös, de még nem is fiu, hanem lány! A zene kellemes, a szöveg tarka, a kiállítás díszes, az előadásban a legjobb erők vesznek részt és Soldosné [Blaha Lujza] a czimszerepben szépen énekel s játszik."28

24 Gellér 2017: 45.

25 Gellér 2017: 79 .

26 A legkorábbi magyar nyelvủ szépirodalmi munkák Vértesi Arnold (1836-1911) A fölkelö nap országa - regényes utazás Japánban (1878) és Sas Ede A felkelö nap hösei - kalandok a japán-orosz háborúban (1904) címü regényei voltak. Ld. bővebben: Tóth 2018: 189-190.

27 Bozó 2013.

28 Vasárnapi Ujság, 1877. április 29. 
A Vasárnapi Ujság továbbá beszámol az előadásnak még egy érdekes mozzanatáról: a cirkuszi késdobáló jelenetéről. A történet szerint Koziki, miután kiderül, hogy nő, egy utcai zsonglörrel szökik meg, így lehetöség volt különböző akrobatikus és cirkuszi elemek beépítésére az előadásba. A ,japáni specialitásként" emlegetett jelenetet feltételezhetően a különböző japán utazó akrobatacsoportok ihlethették, amelyek elsőként hagyták el a szigetországot a „nyugati nyitást” követően, és több éven keresztül az első színházi társulatok - többek között a Kawakami-társulat - turnéjáig az európai közönség csak ilyen jellegű előadásokat láthatott japán előadóktól.

A második nyugati szerzők tollából származó japán témájú előadást szintén a Népszínházban mutatták be 1886. december 10-én. A William S. Gilbert és Arthur Sullivan által írt két felvonásos operett, A mikádó vagy Titipu városa ,angol termék, $\mathrm{s}[\ldots]$ meglehetősen letér az operettek által taposott ösvényröl. Szövege is egészen más világból meríti tarkaságait, Japánból, s tele van mulatságos elemekkel, elmés és kellemes fordulatokkal". ${ }^{29}$ A darab sikerét mutatja, hogy már egy évvel az angol Savoy Theatre-ben tartott ősbemutató után ${ }^{30}$ Európa szerte müsorra került, és 1907-re filmverzió is készült belőle. ${ }^{31}$ Evva Lajos, a népszínház igazgatója is meglátta az előadás bécsi vendégszereplése alatt a lehetőséget: ez az alkotás „forradalmasíthatja a zenés színpadot”, ${ }^{32}$ és felfrissülést jelenthet a bécsi és francia operettek mellett. A hazai előadás - amely Rákosi Jenő fordításával, valamint Erkel Gyula és Elek hangszerelésével történt az angol zongorakivonat után ${ }^{33}$ - sikeresnek mondható a kritikák és a nézőszám alapján, továbbá a népszínházi bemutatót követően 1891-ben és 1905-ben felújították, valamint 1900-ben a Magyar Színház is müsorra tüzte. Fontos mérce lehet továbbá, hogy az előadásból egyfelvonásos paródia is készült Der Mizekado, oder Ein Tag in Pititu (Az almikádó, avagy egy nap Pitituban) címmel, amelyet 1888. december 2-án a budapesti Gyapjú utcai Német Színházban mutattak be. ${ }^{34}$

A fiktív Japán városban, Titipuban játszódó történet, sok szerelemmel, ármánnyal és egy banális törvénykezéssel, valamint annak komikus következ-

29 Vasárnapi Ujság, 1886. december 19.

30 Londonban 1885. március 14-én mutatták be és két éven át 672 alkalommal játszották.

Ld.: Bradley 2016: 623.

31 Traubner 2003: 168.

32 Gál-Somogyi 1960: 320.

33 Gál-Somogyi 1960: 320-321.

34 Vö.: Bozó 2016: 352, 357. 
ményeivel azonban távol állt a valódi japán elemektöl. A Sullivan által írt zene - leszámítva pár japán hatású pentaton skálát a nyitó kórusban és az egyik leghíresebb katonai indulót, a Miya samát - alapvetően az angol népdalok világából táplálkozott. ${ }^{35}$ „Az ilyesféle [japán] zenei kolorit alkalmazása persze nem több puszta felszínnél.. ${ }^{36}$ A japán zenét nem találták érdemesnek a nagyobb mértékü felhasználásra, mivel amit Báró Raimund von Stillfrednek a bécsi világkiállításon megfogalmazott, általános véleménynek számított. Szerinte a hagyományos japán zene és a bécsi valcer „közti nagyfokú hasonlóság abban rejlik, hogy mindkettő képes lábunkat mozgásra indítani - az előbbi táncra, míg az utóbbi menekülésre késztet". ${ }^{37}$ Az idegen és az európaitól eltérő hangzás miatt tehát még a japán témájú zenés előadásokban sem használtak autentikus zenét. Vagyis a japán témájú és helyszínű előadások csupán a ,japán divat" termékei voltak.

„A szokatlan helyszínválasztás célja persze nem is valamiféle folklorisztikailag hiteles Japán reprodukciója lehetett:, [...] az egzotikus színpadi téma vonzerejét a látványos díszletek és jelmezek lehetősége mellett talán inkább az adhatta, hogy a távoli és idegen civilizáció jelmezeinek és kulisszáinak leple alatt nevetségessé lehet tenni a saját, honi viszonyokat." 38

Utóbbi megállapítás talán kevésbé volt releváns a magyar közönség számára, a látvány terén viszont minden sztereotip lehetőséget felvonultattak.

„Az előadás is sok olyan sajátosságot kiván, melyek az operettek burleszk világában szokatlanok s épen azért jól hatnak. Ilyen a japáni szokások szerinti mozgás, a legyezőkkel való folytonos gesztikuláció, mely a csoportokban, az énekkarok föllépésében csinos elevenséget hoz a szinpadra." ${ }^{39}$

A magyar előadás díszlettervei nem maradtak fenn, de feltételezhető, hogy - akárcsak a zene és a táncok esetében - minden a londoni produkció mintájára készült, ehhez viszont az 1885-ben Knightsbridge-ben megnyílt japán falu szolgáltatta az ihletet. A mesterségesen létrehozott falu valójában

\footnotetext{
Bradley 2016: 625.

Bozó 2016: 353.

Dénes 2012a.

Bozó 2016: 353.

Vasárnapi Ujság, 1886. december 19.
} 
egy tipikus néprajzi kiállítás volt, ahol ezer japán férfit, nőt és gyermeket mutattak be a közönségnek autentikus boltokkal, teaházakkal, szentélyekkel és színházakkal.

Az első néprajzi kiállítást 1874-ben Carl Hagenbeck (1844-1913) hívta életre. ${ }^{40}$ Az Európa különböző állatkertjeiben és panoptikumaiban bemutatott népcsoportokon keresztül Hagenbeck

„a másság hozzáférhetőségének és hitelességének idegborzoló illúzióját úgy teremti meg, hogy a magas szinten megalkotott müvi, imaginárius terekben elmossa, illetve megtagadja a fennálló távolságokat, miközben a szemlélő számára mindvégig fenntartja a biztonság tudatát". ${ }^{1}$

Vagyis az embereket hasonló körülmények között mutatták be, mint az állatkertek egzotikus vadállatait. Ez önmagában a látvány és a vágyott másság megismerése miatt is csábító volt, nem beszélve arról, hogy ezek a találkozások veszélytelenné és ellenőrizhetővé váltak a néprajzi kiállításokon. Emellett a publikum szórakoztatására megjelentek a különböző valós és indokolt események nélküli táncok, rituálék, speciális képességek bemutatását felvonultató produkciók, amelyek idővel jelenetek sorává, majd ismétlődő előadásokká változtak, vagyis a különböző népcsoportok ,tiszteletre méltó szokásaikat látványossággá alacsonyították" ${ }^{42}$ Ezáltal az előadók már nemcsak mint idegen emberek jelentek meg, hanem az ismétlődő szerepfelvételnek köszönhetően egyfajta színészi funkciót is betöltöttek. ,»[T]örténeti kosztümökben bemutatott cirkuszszámokként« egymásba mosták az állatkert és a cirkusz, az etnográfiai kiállítás és a színházi előadások határait."43

Ilyen jellegü esemény volt a knightsbridge-i japán kiállítás is, amely alapján Gilbert inspirálódott, s több japán résztvevőt alkalmazott a londoni bemutató előtt, hogy különböző mozdulatokat tanítsanak a színészeknek. ${ }^{44}$ Ezáltal a londoni előadás sem teljes mértékben hiteles forrásokra támaszkodott, hiszen a néprajzi kiállítások az európai tekintet által szerveződtek, és elsődleges céljuk

40 Az egzotikus és vadállatokkal kereskedő, a modern állatkert megteremtőjeként számon tartott férfi volt az első, aki parkja számára nemcsak különleges példányokat, hanem embereket is rendelt, elsőként egy lapp családot, és feltételezte, hogy ennek a népcsoportnak a skanzenszerü bemutatása megfelelő fogadtatásra talál majd a tudósok mellett nagyközönség köreiben is. Bővebben: Rothfels 2002: 8-9.

Jacobs 2009: 242.

Bitterli 1982: 233.

Jacobs 2009: 244.

Penley 2003: 53. 
nem az autentikus bemutatása, hanem a szórakoztatás és felsőbbrendüség igazolása volt az idegennel szemben.

Lehetséges tehát, hogy voltak az angol és a tőlük átvett magyar előadásokban is például hagyományos japán tánclépések, a fennmaradt magyar mütermi fotók azonban erősen sztereotipizálók, a mozdulatok, jelmezek és föként a legyezők tekintetében. ${ }^{45}$ Utóbbiak számos esetben funkciójukat vesztve, dekorációs elemekként térnek vissza, akár hajdíszként, akár az öltözékhez tartozó kellékként. ${ }^{46}$

A mikádóhoz hasonló tendenciát követett a tizenegy évvel később, 1897. október 16-án a Magyar Színház nyitó előadásaként müsorra kerülő Gésák, vagy egy japáni teaház története címü angol operett is. A Sidney Jones és Owen Hall által írt, 1896 áprilisában Londonban bemutatott mü történetét tekintve akár a Madame Butterfly komikus elődje is lehetne, ahol már nemcsak japán szereplők, hanem amerikai katonák is megjelennek. A szép gésa és a katona azonban az előadás végén még saját, szeretett párjuk mellett kötnek ki. ${ }^{47}$ A Gésáknak még nagyobb sikere volt külföldön, mint $A$ mikádónak, így biztos sikert vártak tőle a Magyar Színház nyitó előadásán Az első lépés címü színjátékot követően:

„Az ünnepélyes alkalom, ugyan eredeti müvet, sőt másfajta szellemet kívánt volna, mint »A gésák«, de a dallamos és fürge operette megtette hatását s igazolta azt a tetszést, melyben külföldi szinházakban részesült. [...] A zene kedves, sőt eredeti. Az előadás jól betanult és sikerült volt." 48

Ezt igazolja, hogy a müvet folyamatosan müsoron tartották, majd 1898-ban Kolozsváron és Temesváron, 1899-ben Nyitrán, 1901-ben Nagyváradon is müsorra tủzték, míg a fővárosban 1912-ben a Király Színház vette át. ${ }^{49}$ Sőt Oroszi Antal által ennek a darabnak is született paródiaverziója Gézák, vagy:

\footnotetext{
Vö.: Belitska-Scholtz-Rajnai-Somorjai (szerk.) 2005: 164-167.

Dénes 2012b: 310.

Vö.: Gál-Somogyi 1960: 316-317.

Vasárnapi Ujság, 1897. október 24.

Gajdó 2001: 180. Valójában 1897 és 1901 között szinte nem volt olyan város, ahol ne mutatták volna be a darabot, így mikor Kosztolányi a Pacsirta című regényébe is beemeli, a korszak egyik legtöbbet játszott, gyakran neves színésznők jutalomjátékaként feltünő előadását teszi meg regénye egyik központi elemének. Ehhez ld. Koósz István felbecsülhetetlen értékü munkáját: Koósz 2019.
} 
egy tabáni kávéház története címmel, ${ }^{50}$ illetve Kosztolányi Pacsirta címü regényének a hatodik fejezetében ezt az előadást nézik a szereplők. ${ }^{51}$

A magyar ősbemutató színpadképéről szintén nem maradtak fenn adatok, itt is csupán mütermi fotók adnak bizonyosságot például a legyezők és papírernyők maximális és már-már túlzásba eső (ki)használtságáról. A Király Színházban játszott előadásról ellenben vannak archív felvételek, melyek nagymértékủ hasonlóságot mutatnak (félköríves fahíd, leomló lilaakác füzérek stb.) a korabeli Kameido Tenjin szentély látványával. A töménytelen mennyiségü virágdekoráció is része volt a „tipikusan japán” elképzelésnek, a kert kapcsán - köszönhetően az ukiyo-e metszeteknek és a japonizáló festményeknek - mindig a fiatal hölgyek (esetleg gésák) és a virágok kavalkádjára asszociált az európai közönség. A Gésák londoni és így feltételezhetően magyar díszletében is (utal erre a Magyar Színház plakátja) lilaakácfüzérek omlottak alá a teaházról, majd a később megjelenő kertet krizantémok borították. Hogy ez a megoldás is csupán a nyugati sztereotípiákat szolgálja ki, bizonyítható azáltal, hogy Japánban lilaakácot szinte alig futtatnak házakra, illetve a kertekben a krizantém ősszel virágzik, szemben a tavaszi akáccal. ${ }^{52}$ A díszletben megjelenő épületelemek ugyan megegyeznek a korabeli japán építészet jellegzetes elemeivel, de a vizuális megjelenítésnél tovább nem mennek. Feltételezhető tehát, hogy a Gésák díszlettervezője már különböző Japánban készült fényképek és fametszetek felhasználásával, a japán építészet ismeretével hozta létre a színpadképet. ${ }^{53}$ Ezáltal már lényegesen jelentősebb volt az autentikusságra való törekvés, mint $A$ mikádó esetében, de a fó motiváló erő még mindig a ,japános látvány” létrehozása volt, amelynek érdekében az „eredeti” háttérbe szorult a sztereotip ábrázolás és a különböző jellegzetes elemek halmozása miatt.

Ezzel kapcsolatos áttörést David Belasco drámájának, a Pillangókisaszszonynak a bemutatója sem hozott 1901. október 15-én a Vígszínház színpadán, annak ellenére, hogy a korabeli sajtó kiemelte, a föszerepet játszó Pálmay Ilka találkozott Sadayakkóval és ,tanúlt tőle néhány japán tánczot. A Pillangó kisasszony ruháit is Sada Jakko kosztümjei mintájára csináltatta". ${ }^{54}$ A szóban forgó csipkés, fodros ujjú ruhadarab azonban távol áll az autentikus

\footnotetext{
Bemutató: 1898. január 29. Folies Caprice.

Vö. Tarjányi 2016: 38-39.

Kawaguchi 2016: 16.

Dénes 2012b: 308, 314.

Pásztor, 1901. október 27.
} 
japán viselettől, inkább a népszerü, európai divatot követő japán stílusú köntösökre hasonlít. ${ }^{55} \mathrm{~S}$ bár a hagyományosságra való törekvés szándéka nagyon látványosnak volt mondható, mint $A$ Hétből később kiderült, nemcsak Pálmay köntöse, hanem a „termete, szava, mozdulata [is] mind csupa nyugatiság” volt, hiába mondták „Sada-Yacco-kópiának” ${ }^{56}$ Vagyis ebben az esetben is elegendő volt csupán a japán hangulatot megidézni a közönség számára.

Elmozdulás figyelhető meg azonban a Pillangókisasszony opera bemutatóján 1906. május 12-én. Puccini, aki maga is jelen volt a magyarországi bemutatón, rendkívül nagy figyelmet fordított a részletekre, és felügyelte a megvalósulás körülményeit. ${ }^{57}$ Így érthető, hogy a budapesti közönség a két évvel korábbi, a milánói Teatro alla Scalában tartott ősbemutató díszletelemeit láthatta a színpadon, amelyek már pontosabban törekedek Japán megidézésére. Cho-Cho-San szobáján például - amely a második felvonás hátterét adja a Shoin-zukuri építéteszeti stílus jegyei ismerhetők fel. A stílus jellemzője, a tágas és gazdagon, föként fafaragásokkal díszített szobák, a főuri házakban jelentek meg a XV. és XVIII. század közötti időszakban. Cho-Cho-San története azonban az 1800-as évek második felében játszódik, így annak ellenére, hogy az opera már törekedett a hiteles japán díszlet színpadra állítására, autentikussága nem egyezik meg a korszak építészeti stílusával. ${ }^{58}$

Összességében elmondható tehát, hogy a századforduló Magyarországán bemutatott, nyugati szerzőktől ${ }^{59}$ származó japán témájú előadások főként a nyugat-európai ösbemutatók díszletelemeit és jelmezeit másolták, és sokkal inkább törekedtek az európai közönség fejében élő „,varázslatos és egzotikus”

55 Az európai közönség a kimonókat elöször a fametszetekről és a japonizmus hatására készült festményekről ismerte meg. A ruhadarab az 1880-as évekre divatos otthoni ruhadarabbá vált, egyfajta köntössé, amelynek semmi köze nem volt már az eredeti japán hétköznapi viselethez. A ruhadarabot derékig szétnyitva, lazán megkötve vagy az övet teljesen elhagyva viselték. Vö.: Fukai, kci.or.jp.

56 Emma, 1902. december 7.

57 A „korszak nagy operaprodukcióinak bemutatása gyakran zajlott azonos séma szerint. Puccini esetében e sémát a hivatalos kiadó, Giulio Ricordi engedélyezte, s a darab minden egyes bemutatójához ugyanúgy kölcsönözni és követni kellett a hivatalos díszletek és jelmezek terveit, mint a librettót, a partitúrát vagy a mise-en-scène-t, mely a bemutatási jogok megvásárlásával együtt járt” Dénes 2013.

8 Dénes 2012b: 314-315.

59 Az első magyar szerzőktől származó japán témájú előadások (Szikra) Teleki Sándorné: A csodaváza (Operaház, 1908. 05. 09.), Lengyel Menyhért: Taifun (Vígszínház, 1909. 10. 30.), Farkas Imre: Narancsvirág (Uránia, 1910.11.24.) és Kállay Miklós: A roninok kincse (Nemzeti Színház, 1936. 04. 24.) voltak. 
Japán-kép kielégítésére, mint a hitelességre. A japanizáló előadások és az angol operettek sikere azonban azt jelzi, „hogy a közönségigény a századfordulóra megváltozott, a publikumot a dinamikus színpadi mozgás és a színes látvány hatása kápráztatta el". ${ }^{60}$

\section{Japán előadások Magyarországon}

A Kawakami-társulat 1902-es érkezése előtt Magyarország területén csupán a hagyományos japán színjátéktól távol álló akrobata- és zsonglőregyüttesek jártak, amelyek a Meiji-megújulást megelőzően az elsők között hagyták el Japánt. 1866 és 1867 között hét akrobatacsoport indult amerikai körútra, amelyből egy eljutott Londonba, majd az 1867 -es párizsi világkiállításon is szerepelt. ${ }^{61}$

A magyar közönség elöször 1868 januárjában a Budai Népszínházban üdvözölhette a Niigatából érekezett Echigo Kakubei Jishi, vagyis az echigói Kakubei Sárkány társulatot, amely európai körútjuk során látogatott el Magyarországra. A társulat január 8. és 15. között lépett fel Molnár György színházában, fő attrakciójuk a látványos egyensúly- és ügyességi müsorszámok mellett a 10 év alatti gyerekszereplök felvonultatása volt a különböző müsorszámokban. ${ }^{62} \mathrm{Az}$ előadások menetéről és a bemutatott müsorszámokról hoszszabban Réthi Lajos írt, aki szerint ,annyival jelesebbek eme japáni erőmüvészek a mieinknél. [...] Az egészben nincsen semmi büvészi; egyszerü természeti törvények egyszerre megérthető alkalmazása csupán: hanem oly magas tökélyre fejtett alkalmazás, hogy az ember alig tartaná hihetőnek" ${ }^{63}$ A müsor hat számból állt, ${ }^{64}$ és valójában nem is akrobata-, hanem ahogyan a Vadász és Versenylap fogalmaz ,erőmütani mutatványoknak” lehet őket nevezni, mivel „mutatványaik legnagyobb része a passiv erő és egyensulyozás hihetelenségig fokozott mértékeit mutatja fel". ${ }^{65}$

Ezt követően 1885-ben szerepelt Kolozsvárott és Nagyváradon a Torikata Császári Együttes Charles Arbre ${ }^{66}$ müsorának második felében, és a korabeli

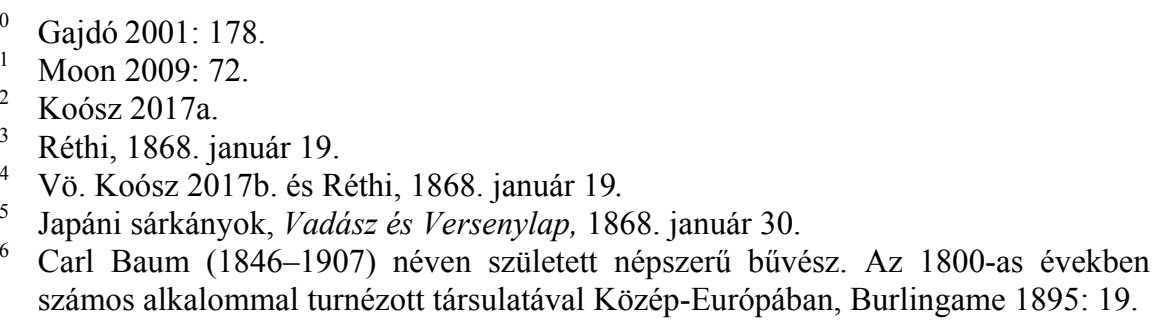


leírások alapján ebben az esetben is különböző akrobata- és erőművészi mutatványokat láthatott a közönség. ${ }^{67}$ 1888-ban a fövárosban és Nagyváradon láthatták az érdeklődők az akrobata Mitsuta társulatot, illetve 1889-ben Debrecenben a „Kamaritz csoportot Edóból”. ${ }^{68}$ 1894-ben pedig a Somossy Orfeum színpadán japán kardvívók szerepeltek nagy sikerrel. ${ }^{69}$

A magyar közönség tehát csupán ezekkel az akrobata- és erőmüvészcsoportokkal találkozhatott, Sadayakko és a Kawakami-társulat 1902-es budapesti fellépése elött. Ráadásul az átlagemberek nagyon kevés információval rendelkeztek a japán színházról általában. ${ }^{70} \mathrm{Az}$ egyik legelső sajtóközlemény a Sámi Lajos által publikált Japán hajdan és most cikksorozatának befejező része volt, ${ }^{71}$ amely személyes élményei alapján a japán színházra is kitért. Terjedelmes írásában vázolja a fóváros színházainak, mulatóinak elhelyezkedését, kinézetét, majd kitér az előadásokra is, amelyek véleménye szerint „hasonlíthatatlanabbul költőiebbek, naivabbak, szenvedélyesebbek és [...] emberiebbek", ${ }^{72}$ mint a nyugati előadások, de azt is hozzáteszi, hogy ,a japániak magasabb rendủ drámáját nem tarthatjuk eredetinek; ők nem járnak saját lábaikon ebben a tekintetben hanem még mindig a khinai mintákat utánozzák [...]" ${ }^{73}$ A cikk mellet egy kabukiszínpad korabeli képe is látható, és az előadás menetének leírása is - számos torzítással, félreértelmezéssel - a $k a$ bukit idézi. Szintén ennek a színjátéktípusnak a bizonytalan körvonalai idéződnek meg A színház Japánban címü cikkben ${ }^{74}$ ahol a színészek társadalmi helyzetéről és a híres kabukiszínészek nevéről is tájékoztatták a korabeli közönséget. A szöveg szerzöje azonban hangsúlyozza, hogy a japán színpadon egyfajta torzulás fedezhető fel, ahol embertelen, fantasztikus lények és gyakran állatok is megjelennek. ,[E]gyetlen müfaj létezik náluk: a dráma. És milyen dráma! A milyen a lázas izgalmakra szomjuhozó tömegnek tetszik: összeesküvés, párbaj, banditák, rablógyilkosság, irgalmatlan bosszu, öngyilkosság, szerelmi ármány s efélék..." ${ }^{, 75} E$ felsorolás alapján összességében a japán színház valamiféle könnyen érthető, melodrámához hasonló müfajnak

\footnotetext{
Vö. Arbré jeles társasága, Magyar Polgár, 1885. július 25.

Dénes 2019.

Molnár Gál 2001: 152.

Koósz 2019.

Sámi, 1875. november 14.

Uo.

Uo.

A szinhaz Japánban, Budapesti Hírlap, 1900. március 9.

Uo.
} 
tünhetett a magyar közönség szemében. Közvetlen Sadayakko budapesti fellépése elött ellenben hosszú magyarázatát találjuk a Budapesti Hírlapban annak ${ }^{76}$ hogy az európai néző valójában miért nem képes érteni és értékelni a japán színházat, amely a „multnak hamisitatlan képe”. ${ }^{77}$ A korszak naturalista-realista színházából kiindulva a cikk szerzője azt várja, hogy a „valóság” tükröződjék vissza a színpadon, és ennek megvalósulása komoly előfeltételeket kíván, vagyis hogy „a külső dolgot olyan formában mutassuk be a színpadon, a mint megszoktuk és a mint esztétikai nevelésünk alapján méltatni is tudjuk. Már pedig, ha japáni müvész lép föl európai színpadon, nem találja meg ezeket az előfeltételeket”. ${ }^{78}$ A színpadon „primitív drámai eszközöket” használnak, amely egykor Európában is megtalálható volt, de azóta „,ölfogásunk fejlődött, szépészeti érzékünk finomodott" ${ }^{79}$ Az előadás megértését gátolja továbbá a nyelv és a tárgy ismeretének hiánya, és az idegenszerü esztétikája is, amely a szerző véleménye szerint nem képes hatással lenni a közönségre. „[E]redetiségét elismerjük, de egyúttal a succés d'estimé határán túl terjedő elismerést nem tanúsítunk." ${ }^{" 80}$ Mindenért pedig a japánok gyermeki lelke és a fantasztikum iránti dolgokért való lelkesedése okolható, mondja, amely visszatér a japán színpadi hősök jellemében is, akik európai színpadon állva csak torzképek lehetnek. Az egyetlen közös, ,nemzetközi” pont: a halál. S mintegy elővezetve Sadayakko érkezését utal rá, hogy ez az egyetlen dolog, ami képes lenyűgözni az európai közönséget.

„Egyik európai kritikus a japáni társaságról irva, azt állította, hogy müvészetük csak akkor hatja meg, ha a színész haláltusáját látja, a melyet mesterileg játszik meg. E megjegyzés igen jellemző. Könnyen megérthető, hogy oly jelenetekben, a melyekben közös valóság van, az idegen müvészet is gyakorolhat ránk hatást. Nemzetközi jelenetnek tekinthetö a halál formája, a melyben a japáni művész szintén ismert nyelven beszél hozzánk és mi részvéttel követhetjük az előadás fonalát." ${ }^{81}$

A japán színház iránti érdeklődést pedig éppen Sadayakko mozdítja elöre, mivel budapesti fellépése alkalmából a róla szóló számos sajtóközlemény

\footnotetext{
oh, 1902. február 25.

Uo.

Uo.

Uo.

Uo.

Uo.
} 
mellett, a Vasárnapi Ujság terjedelmes leírását adja A japáni dráma és szinpad címü cikkében. A beszámoló egy amerikai újságíró személyes tapasztalataira támaszkodik, aki szerint ,a japáni dráma és szinművészet [...] erősen realisztikus, s e mellett nagy hajlama van a borzalmas, véres eseményekre". ${ }^{82}$ Alapvetően ez az írás is a kabuki jellegzetes elemeit emeli ki (a legtöbb esetben pontatlanul), beszámol a kabuki színpadáról, a színészek játékmódjáról és szerepköreiről, illetve kitér a müfaj kialakulásának a történetére, Okunira és a női kabukira. Fontos, hogy megemlíti a rendeletet, amely feloldja a nők színpadon való szereplésének betiltását (a cikk 1881-es dátumot jelöl, valójában 1877), ${ }^{83}$ és ezzel igazolja, hogy nem is Sadayakko az első hivatalos színésznője az országnak, ez csupán egy reklámfogás. ${ }^{84}$ Utóbbi megállapítás főként azoknak a cikkeknek a tükrében érdekes, amelyek több ízben arról számoltak be, hogy a tilalmat Sadayakko kérésére Viktória királynő eszközölte ki a japán császárnál, miután látta Sadayakko előadását. ${ }^{85}$ Az esetre azonban Kawakami Otojirō és Sadayakko elmondásán kívül nincs bizonyíték, így feltételezhető, hogy ezzel a gesztussal csupán sikereiket akarták legitimálni és még nagyobb szenzációt kreálni a társulat körül, mely - tekintve a budapesti sajtótermékek Sadayakkóról szóló cikkeit - teljes mértékben sikerült.

\section{Sadayakko Budapesten}

Annak ellenére, hogy a korabeli sajtóban a japán színházról kevés valós tájékoztatás jutott el az emberekhez, annál több különböző információt lehetett olvasni Japán első színésznőjéről, „Sada Yacco-ról”. ${ }^{86}$ Lényegében Európába való első érkezésüktől, vagyis 1900 júniusától már lehetett hallani a ,japáni szinészekről”, akik előbb Londonban, majd a párizsi világkiállításon léptek fel.

82 A japáni dráma és szinpad, Vasárnapi Ujság, 1902. március 2.

83 A kabukit 1602-es kialakulását követően nők adták elő, prostituálódásuk miatt azonban a sógunátus 1629-ben megtiltotta a nők színpadon való megjelenését, amely rendelet egészen 1877-ig érvényben volt. A kabuki történetéről bővebben: Doma 2017.

84 A japáni dráma és szinpad, Vasárnapi Ujság, 1902. március 2.

85 Ld. Sada Yacco, a »japán Duse«, Budapesti Napló, 1900. szeptember 13.; Egy japán primadonna, Pesti Hírlap, 1900. szeptember 13.; Saday Yacco: Életemből, Budapesti Napló, 1900. szeptember 19.

86 Egységes átírás nem lévén, a sajtótermékekben több átirata szerepel a névnek (Sada Yacco, Sada Yakko, Szada Yacco, Szada Jakko stb.), amelyek közül a leggyakrabban használt a Sada Yacco volt. 
A Pesti Hírlap számolt be elsőként a Coronet Theatre-ben szereplő csoportról, akik európai mintákat másolnak, ez látszik például $A$ gésa és a lovag címü előadásukon is, és az egész társulatról általában elmondható, hogy nincs bennük eredetiség. ${ }^{87}$ Az újság következő számában azonban már Sadayakko nyilatkozatát közli az angol nőkről és az európai divatról, a japánok számára erkölcstelen színpadi viselkedésről, valamint összehasonlítja a japán és a nyugati közönséget ${ }^{88} \mathrm{~A}$ társulatról még több részletet lehetett megtudni a világkiállításon való szereplésük ideje alatt, bár a megjelent cikkek legtöbbje a primadonnáknak kijáró, szenzációkeltő, bulvárjellegü írás volt. Szintén a Pesti Hirlapból értesülhettek az olvasók Loïe Fuller szerepéről a társulat életében és Sadayakko híressé vált játékáról és haláljelenetről, amelyben Adolphe Brisson, a Temps kritikusa szerint

„a legnagyobb realizmus a legnagyobb idealizmussal egyesül. Nincs mủvésznő szerinte, aki annyi realizmussal s mégis oly fölséges szépen tudna meghalni a színpadon, mint ez a csúf japáni asszonyka. [...] Aki azonban csak egyszer is látta Sada Yaccot, örökké emlékezni fog rá $\mathrm{s}$ a jelenkor egyik legnagyobb művésznőjét fogja tisztelni benne." 89

Az érdeklődés fokozódását mutatja, hogy a következő hónapban a Budapesti Napló Sadayakko életrajzát is közölte, amely - a színésznő valódi életrajzát ismerve - kiválóan rámutat az önreprezentáció sikeres manipulációjára. A magát 23 évesnek valló (valójában 29) színésznő beszél férje otthoni sikereiröl, politikai karrierjéről, magát pedig nem mellesleg mintegy a körülmények áldozataként mutatja be, aki kényszerüségből vált színésznővé, de már első fellépésén hatalmas sikert aratott, amelyet viszont a japán nőkhöz méltó „visszafogottsággal” kezelt:

„A bátorság erőt adott és diadalt arattam! Tízszer kellett a darab végén a közönség elött megjelennem, amely a színpadra akart tódulni, hogy engem diadalmenetben elvigyen, de én megszöktem az ovációk elől. Ez volt a bemutatkozásom." 90

A tények tehát „kozmetikázva,” tündérmeseszerüen térnek vissza a sajtóban. Szükség is volt erre a szimpátiára és az érdeklődés fenntartására, ugyanis már

\footnotetext{
Japáni szinészek, Pesti Hirlap, 1900. június 1.

Japáni szinészek, Pesti Hírlap, 1900. június 2.

Sada Yacco, Pesti Hirlap, 1900. augusztus 5.

90 Sada Yacco: Életemből, Budapesti Napló, 1900. szeptember 19.
} 
ebben a cikkben olvasható a Vígszínház bejelentése, amely szerint vendégszereplésre hívják a müvésznőt. A terv azonban a társulat korábbi elkötelezödései és novemberi hazatérésük miatt meghiúsult, de kilátásba helyeztek egy látogatást 1901 tavaszára. ${ }^{91}$ Ezt követően több fórumon is hír volt, hogy a Vígszínház müsorára kívánja tüzni $A$ gésa és a lovagot, és a föszerepet Jászai Mari fogja alakítani. ${ }^{92}$ Az előadás ugyan nem valósult meg, de a Vígszínház közönsége nem maradt japán témájú előadás nélkül, mivel 1901 októberében repertoárra került a már említett Pillangókisasszony Pálmay Ilka föszereplésével, amelyhez közvetetten Sadayakkónak is köze volt. Az 1901 tavaszára ígért magyarországi látogatás végül csak 1902 elején valósult meg, és a társulat érkezését beharangozó írásokon kívül már csak egy komolyabb, kritikusabb hangvételü írás jelent meg Erényi Nándortól, aki Londonban látta a társulatot európai turnéjuk kezdetén. Erényi több ízben hangsúlyozza - mintegy ellentmondva a magyar sajtóban megjelent korábbi magasztaló cikkeknek - hogy Londonban Sadayakko „hirneve nem mint müvésznagyságé, hanem mint exotikumé terjengett". ${ }^{93}$ Az előadott darabokban (A gésa és a lovag, Kesa) kizárólag Otojirō verekedés- és Sadayakko haláljelenetei váltottak ki hatást, de a szerző szerint ez is csak az egzotikumnak köszönhetö, nem a müvészi kivitelezésnek:

„A gyerekarcu, szögletes és kistermetü diva szerelmi óbégatásait és különös fintorait azzal a bizonyos mosolylyal fogadták a nézőtéren, sokáig húzódó, tulozottan realisztikus haldoklását azonban komoly figyelemmel nézték és lelkesen megtapsolták. Ez a világhírüvé vált haldoklási jelenet - sok-sok reflex-rángatózással és csukló sóhajjal - tetszett a londoni közönségnek, amelyet - úgy láttam - megint csak a do$\log$ exotikuma fogott meg." 94

Írása végén Sadayakko közelgő budapesti fellépése kapcsán felteszi a kérdést, vajon a magyar közönség művészetnek vagy csupán látványosságnak ítéli-e majd az előadásokat.

Összességében az 1902. február 22-én Budapestre érkező Kawakami-társulat tízestés szereplése - néhány negatív kritikát leszámítva - sikeres volt.

\footnotetext{
91 Sada Yacco a japán primadonna a Vigszinházban, Pesti Hírlap, 1900. szeptember 26.

92 Japáni darab a Vigszinházban, Pesti Hirlap, 1900. december 27. és A gésa és a lovag, Budapesti Napló, 1900. december 30.

Erényi, 1902. február 19.

94 Uo.
} 
Még aznap este megtartották nyitó előadásukat az Uránia színpadán $A$ gésa és a lovaggal, illetve a Kesával, amelyek tartalma az aznapi Pesti Hírlapban is olvasható volt. ${ }^{95} \mathrm{Az}$ ismertető, mintegy „,vezetve” a közönség befogadását - amelyre a darab idegensége miatt feltétlenül szükség volt - rámutatott, hogy kifejezetten a haláljelenetekre kell figyelmet fordítani, mivel azoknak ,müvészi realizmusa az egész darab pièce de resistance-a”. ${ }^{96}$ A Vasárnapi Ujság emellett azt is hangsúlyozta, hogy a magyar közönségnek először van lehetösége komoly japán müvészetet látni, és Sadayakko, ,a ki európai mértékkel mérve is igazi művészi tehetség s nagy hatást tud, különösen játékának realizmusával elérni". ${ }^{97}$ A nagyfokú érdeklődést mutatta, hogy jegyeket már február 15-tól lehetett váltani a produkciókra, és az egy hét alatt a társulat a teljes repertoárját felvonultatta, amelyből csak Otojirōnak $A$ velencei kalmár átdolgozása aratott kisebb visszatetszést:

„Nagyon kevesen voltak tanui annak a félig vad, félig gyerekes kegyetlenségnek, melylyel kedves japán vendégeink a nagy brit alkotás nyakát kitekerték. De hát ezúttal is ismételjük: nem arról van szó, hogy a japánoknak a mienknél fejlettebb színpadi művészetét megcsodáljuk, hanem tudomásul vegyük, milyen az a sárga müvészet s micsoda közökön keresztül, bármily primitiv technikával is meg tud nyilatkozni az éghajlatoktól és kulturális fokoktól független müvészlélek." ${ }^{98}$

A japán színjátszás tehát nem „fejlettebb” a nyugatinál, sőt primitív technikával él, de Otojirō Shylock szerepét ,akkora müvészettel, bármely európai szinésznek is becsületére váló pszichologus hüséggel játszotta meg, hogy nagyot nőtt elöttünk". ${ }^{99}$ Míg a Magyarország címü napilap primitív kultúrának tüntette fel a japánt, addig a Vasárnapi Ujság egyfelől elismerte a társulat érdemeit, értékelte, hogy ,a dolgokat szinte hihetetlen realizmussal játsszák” ${ }^{100}$ másfelől azt állította, hogy a

„japáni szinészek játéka nem olyan természetü, hogy valami hatást lehetne tőle várni az európai múvészet fejlődésére. [...] Azért mégis nem csupán a kuriózum kedvéért érdekes Szada Yakko és társulata, ér-

\footnotetext{
Sada Yacco az Urániában, Pesti Hirlap, 1902. február 22.

Uo.

Japáni szinészek, Vasárnapi Ujság, 1902. február 23.

A japán velencei kalmár, Pesti Hirlap, 1902. február 27.

Uo.

100 Japáni szinészek, Vasárnapi Ujság, 1902. február 23.
} 
dekesnek kell találnunk őket, mint a mienkkel ugyan ellentétben álló, de bizonyos irányban rendkívüli fejlettségü müvészet képviselöit is, a kik a maguk nemében nagy dolgokat csinálnak s nagy hatást tudnak elérni.",101

Alapvetően elmondható tehát, hogy a magyar sajtó - hasonlóan az többi nyugati újsághoz - az európai-japán, fejlett-primitív, realista-stilizált, sokszor kirekesztő relációban vizsgálta Sadayakko fellépéseit, már ha egyáltalán azt vizsgálta, és a cikk írója nem egy anekdotát osztott meg az olvasóival. Ezáltal azok a megnyilvánulások, amelyekben Sadayakkót és Otojirōt „európai színésznek” vagy „európai mértékkel mérve is igazi művésznek”, netán „realisztikusnak" ítélik, egyszerre elismerése és kirekesztése is az idegennek.

Arról, hogy a magyar közönség „valójában” mit láthatott, tehát hogy milyen volt a színpadkép és a színészi játék, kizárólag a Vasárnapi Ujság írt részletesen. Ebből kiderül, hogy az előadások némajátékszerüsége miatt a fö hangsúly a szereplők mimikájára került, és ezzel igyekeztek kifejezni minden érzelmet. Ehhez mérten a mellékes szerepet betöltő beszéd egysíkúnak tűnt. A cikk szerzője szerint tökéletesen látszott a színészek mozdulatain a tervszerüség, tetten érhetők voltak tehát a kabuki és a shinpa meghatározott mozdulatai, sémái. ${ }^{102} \mathrm{~S}$ ugyanez igaz Sadayakko haláljelenetére is, amelyben szinte minden az arcon játszódott le, ${ }^{103}$ és valódi testmozgás alig társult a jelenthez:

„[A] gyötrelem minden változatát hiven utánzó arczjátékával, [...] szinte elfeledteti az emberrel, hogy csak a valóság látszata van itt előtte, s nem maga a valóság. [...] Testmozgása kevés, hangjának is alig veszi hasznát, de a mimikájában benne van a fájdalom, a remény, a kétségbeesés minden árnyalata, meglátszik rajta a végjelenetekben a halálkín rettentő vonaglása." 104

101 Uo.

102 Szada Yakko és társulata Budapesten, Vasárnapi Ujság, 1902. március 2.

103 Ezt az arcot és jelenetet próbálta meg - más európai művészekhez hasonlóan - egy magyar festő, Jantyik Mátyás (1864-1903) is megörökíteni, és egy kisméretü olajfestményt készített a színésznőről, amelyet február 28-án, elutazása előtt egy nappal a Royal Szállóban át is adott neki. A Vasárnapi Ujságnak a látogatásról közölt részletes beszámolójából az is kiderült, hogy a színészházaspár az ajándékért cserébe egy darvakkal díszített, rövid versekkel és dedikációkkal ellátott díszes levelezőlapot nyújtott át a festőnek. A látogatásról, illetve a festményröl és a levelezőlapról részletesen: Láto104 gatás Szada Yakkónál, Vasárnapi Ujság, 1902. március 9. Uo. 
A japán társulat látogatása a magyar színháztörténet szempontjából is fontosnak bizonyult, mivel vendégjátékuk körülményei is hozzájárultak Beöthy László (1873-1931), a Nemzeti Színház igazgatójának pozíciójából való távozásához. ${ }^{105} 1902$. február 26-án jelent meg a Magyarország esti kiadásában egy cikk, amely Beöthy magánvállalkozásáról számolt be az olvasóknak. A Nemzeti igazgatója posztjának méltóságával visszaélve Sadayakko magyarországi impresszáriójaként komoly nyereségre tett szert a japánok Urániabeli fellépésével, amely játszóhelyet ő maga szerezte nekik, ${ }^{106}$ és nem átallott maga is beülni a színház jegypénztárába, hogy felügyelje a „méregdrága” jegyek eladását ${ }^{107}$ amelyet a Nemzeti müsorának a heti szegényes volta is elősegített. A cikk továbbá azzal vádolta Beöthyt, hogy a rendkívül kedvező feltételek mellett a kormánytól kapott 20000 koronát, amelyet ügyei rendezésére kölcsönöztek neki, ebbe a magánvállalkozásba fektette. ${ }^{108}$ Beöthy már másnap hárompontos nyilatkozatot adott ki, amelyben cáfolta az ôt ért vádakat. Tagadta, hogy a vállalkozás üzleti részéhez köze volna (az a Bárd Ferencz és testvére színházi ügynökségé), ő csupán közvetítő volt a helyszínkeresés kapcsán, mivel Loïe Fuller korábbi ismeretségük miatt öt kereste fel. A tudósításokból azonban egyértelműen kiderült, hogy az Urániát hét estére Beöthy bérelte ki fix összegért, amelyet az aznapi bevételből fizettek ki. A fennmaradó nyereség 45\%-a a japán színészeket illette meg, míg az 55\% egyenlő arányban oszlott el Fuller, Waldmann Imre és Beöthy közt. Később Sadayakko is megerősítette Beöthy szerepét az ügyben, mivel a színésznő vonakodott kifizetni a fellépések után fizetendő kötelező illetéket a szegényalapba, mondván, ők csak egy részét kapják meg a nyereségnek, a többi Beöthyé. ${ }^{109} \mathrm{Az}$ általános közvélemény szerint „,a Nemzeti Szinház igazgatói állása összeférhetetlen más müvészi impresszáriói müködéssel". ${ }^{110,111}$ A botrány kapcsán ugyan

105 Beöthy sajtóperbe keveredett és veszített Liptai Károly újságíróval szemben. Az 1901 májusától 1902 áprilisig húzódó ügyben és tárgyalásokon számos visszaélésre derült fény, és végül ezek voltak közvetlen lemondásának okai, tetézve a japán vendégjátékkal. Ld. A Beöthy-Liptai ügy, Hazánk, 1902. április 6.

106 A társulat azért nem tudott az ilyen típusú vendégjátékok esetekben első számú játszóhelyként szolgáló Fővárosi Orfeumban fellépni, mert ott Loïe Fuller vendégszerepelt február 17-től tizenkét napon át. Így az Orfeum igazgatója, Waldmann Imre érintettsége az ügyben ezzel is magyarázható. Vö. Gajdó 2019: 11.

107 A nyolcszemélyes földszinti páholy ekkor hetven koronába került a szokásos tizenhat helyett: Gajdó 2019: 10.

108 Beöthy László - magánvállalata, Magyarország, 1902. február 26.

109 Beöthy László - magánvállalata, Magyarország, 1902. február 27.

${ }^{110}$ Uo. 
még Ady Endre márciusban arról írt, hogy a „szent család”, vagyis a Rákosidinasztia „százkezü”, és Beöthy megmenekülni látszik a bukástól, ${ }^{112}$ áprilisban azonban mégis kénytelen volt lemondani igazgatói posztjáról. Ennek kapcsán a Hazánkban jelent meg egy gunyoros fiktív távirat Sadayakkótól, amely egyértelmüen utal a Beöthy bukásához vezető okokra:

„Kedves impresszárióm! Önt illeti legfájóbb impresszióm. Mért hogy éppen a harakirit tanulta el tőlünk! Oh, bár ne lenne éppen ön japáni tragédiáink áldozata! Hát még a magyar klikkek kínai falai sem nyújtanak menedéket? Nincs mandarini copf, amelybe kapaszkodhatnék? Vigasztalja Önt eme dal:

Ki minket vezérelt a magyar parcellán, Imé, eltört, miként japáni porcellán! Átok sok bírói zord bürokratára, Sírok minden reggel, mig bírok rátára! S bár átkot szór sokra a te szád ajakkó, Örökre szivébe zár hü Száda Yakkó!"113

\title{
Hanako Budapesten
}

\author{
Hanako \\ — Alfréd Kerr költeménye - \\ Mosolygok és ámulva nézem, \\ Bizsergeti a vért, szivet. \\ Japán bizsu, baba egészen - \\ Es művésznő, csupaideg. \\ Nem költői, festői mámor \\ E bájos, apró látomány. \\ A lég fuvoláz és nyivákol \\ Halk, fürge léptei nyomán.
}

\footnotetext{
111 A Beöthy botrányról ld. még: Beöthy László magánvállalata, Hazánk, 1902. február 27.; Beöthy László magánvállalata, Pesti Hirlap, 1902. február 27.; A japáni társaság s a Nemzeti Szinhaz igazgatója, Pesti Napló, 1902. február 27.; Beöthy László és az Uránia, Alkotmány, 1902. február 26.; Beöthy László és az Uránia, Alkotmány, 1902. február 27.

112 Ady Endre, 1902. március 6.

113 Sada Yacco kondoleál, Hazánk, 1902. április 12.
} 
Puha talppal szökik lebegve,

Szük, kis czipellöket tapos;

Most macska, majd a bő köpenybe

Kenguruhoz hasonlatos.

Hogy ért a pipes széptevéshez!

Hogy ugrik és mi csókra kész. -

Halála egy v a k tévedés lesz,

Háton döfi a b u t a kés.

...Sir — nyeldekel — nem tud kimúlni;

Kuporog; ködös a szeme;

Némán vonaglik (pisze nyulfi)

S halódva hajlik lefele...

Japán müvészet, ó, szeretlek,

Most rám fuvallsz, mint egykoron.

Testvére vagy a zöld füveknek

( $\mathrm{S}$ az állatokkal is rokon ...).

${\text { (Kosztolányi Dezső fordítása })^{114}}^{11}$

Hanako - akit a japán színház Sadayakkónál is fényesebb csillagaként emlegettek $^{115}$ - kétszer járt Budapesten, 1908-ban és 1913-ban, illetve 1910 ősze és 1911 tavasza között egy magyarországi vidéki körúton is részt vett. ${ }^{116} \mathrm{Ha}$ nako fővárosi fellépései alkalmával sokkal vegyesebb fogadtatásban részesült, mint korábban Sadayakko. A magyar publikum először 1906-ban párizsi sikerei után olvashatott az új tragikáról, akit IX. Ichikawa Danjūrō unokahúgaként tartottak számon. Vagyis a tokiói császári színház színésznőjeként emlegetett Hanako múvészetét a kabukiszínésztől tanulta. ${ }^{117}$ Később 1908-as berlini vendégszereplése és közelgő budapesti látogatása miatt cikkeztek róla. ${ }^{118}$ $A z$ Ujság berlini munkatársa még egy hosszabb beszámolót is írt a Passage Színházban bemutatott előadásról, amelyet inkább ,naiv szamárságnak” titulált, mint valódi művészi darabnak. A magyar közönség számára sokáig nem derült fény arra, hogy a Loi-Fu által jegyzett darabok nem japánok, hanem

\footnotetext{
114 Kosztolányi 1966: 813.

115 Hanako, Budapesti Hirlap, 1908. május 3.

$116 \mathrm{Az}$ alábbi városokat kereste fel: Pozsony, Pécs, Nagykanizsa, Fiume, Debrecen, Nyíregyháza, Arad, Nagyvárad, Kolozsvár, Szeged, Zenta, Szatmárnémeti, Nagykároly, Marosvásárhely, Lugos, Szabadka, Kassa. Vö.: Koósz 2019.

117 Hanako, Pesti Hírlap, 1906. október 22. és Hanako, Pesti Napló, 1906. november 1.

118 Hanako Berlinben, Népszava, 1908. február 28.
} 
valójában Loïe Fuller szerzeményei, így ebben a cikkben is bírálja a tudósító a számára ismeretlen Loi-Fut, akinek darabja meg sem közelíti a nézők elvárásait, akik - a sztereotípiák mentén - minimum a japán képzőmüvészet szépségeit szerették volna viszontlátni a színpadon. Összességében arra a konklúzióra jut, hogy ,az etnográfiai érdekességen kivül Japán legnagyobb szinésznője alig ad valamit a nézőknek", és ez a színjátszás és kultúra nem más, hanem „gyengébb és alsóbbrendü a miénknél". ${ }^{119}$

Hanako első fővárosi szereplése tíz estére szólt 1908. május 1. és 15. között a Fővárosi Orfeumban, ahol az Otake ${ }^{120}$ címú darabot mutatták be. Feltételezhető, hogy más előadás is müsorra került, de a megjelent beszámolók mind ezt a drámát említik, amelyet sok esetben bírálnak egyszerüsége és bugyutasága miatt, ${ }^{121}$ de ettől függetlenül a közönség japán drámának vélte.

„Primitiv, szánalmas kis romantika; egy lányról, egy félreértésről, egy fiatal halálról. De gügyögve is müvészetet ad és ha hiányzik is mellőle az a kolorizmus, mely az igazi japán színjátékokat a fényhatásaival festi alá: az ujjongást vérvörössel, az elsötétedést komor feketével, szinszórással és suhogó vásznakkal, igy is egész, igy is megkap és igy is értelmes." 122

Ami miatt pedig megkapó az előadás - hiszen a kritikák szerint még a díszlet is a „szokásos” volt ${ }^{123}$ - az Hanako személye. Számos lap kiemeli csacsogó, csicsergő és számukra érthetetlen beszédét, a legtöbb esetben állatias jelzőkkel pillangóhoz, madárkákhoz, fơképp pacsirtához hasonlítják „,csipogását” és „tipegő alakocskáját”, ${ }^{124}$ egy kedves kis cselédlányt írnak le, aki úgy fésülködik, mint egy „kis mókus” vagy mint egy „mulatságos kis majom”. ${ }^{125}$ Annak ellenére, hogy ezekben a kritikákban, csakúgy mint a Kerr-féle költeményben

119 Hanako, Az Ujság, 1908. március 8.

120 A történet, amely egy japán kertben játszódik Otake cselédlányról szól, aki felpróbálja úrnője kimonóját, és kicsinosítva magát abban táncol, amikor megérkezik az úrnő szeretője. Hogy nehogy leleplezze magát, elfordul, és nem válaszol a férfi szerelmes szavaira, aki dühösen távozik. Közben Otake szerelmese is megérkezik, aki viszont felismeri a lányt, és figyelmezteti, hogy vegye le a ruhát, mert bajba fog kerülni. Ez azonban nem sikerül neki időben, mert az úrnője szeretője visszatér, és mivel a lány most sem reagál közeledésére, és a férfi nem ismeri fel, féltékenységében leszúrja. Pl.: Hanako, Az Ujság, 1908. május 4. vagy Dömötör, 1908. május 24.

${ }^{122}$ Nádai, 1908. május 3.

123 „A szin japán kert a megszokott pavilonnal.” Hanako, Budapesti Hírlap, 1908. május 3.

124 Hanako, Az Ujság, 1908. május 4.

125 Erényi, 1908. május 5. 
az állatias jelzők inkább kedveskedők és a furcsaságot, idegenséget hivatottak bemutatni, azt, ami eltér az korszakban megszokott európai művészektől, mégis érzékelhető bennük egyfajta lenézés a „kis japán nő” és a társulat iránt. Az a fajta (le)nézés, amely a néprajzi és gyarmati kiállítások alatt született meg a nyugati szemlélőkben, amikor domináns, hatalmi pozícióból szemlélték a nem egyszer rácsok mögé helyezett és az állatkertekben kiállított idegen népcsoportokat. Színpadon látva a Másikat a nyugati néző eltérő pozícióba kerül, de - mint ahogy a kritikák is jelzik - domináns attitüdjét az idegen társulatokkal szemben nehezebben küzdi le, és az állatias, lekicsinylő (szép baba, bábu) jelzők rendre felbukkannak, és mint a későbbiekben látni fogjuk a durva rasszizmus táptalajául is szolgálhatnak. Az Otake esetében viszont a hasonlatok inkább az előadás első felének komikusságára, a cselédlány bőrébe bújt színésznő szándékos ügyetlenkedésére is utalhatnak, amelyet Erényi Nándor egyszerüen „harminc perc Vaudeville”-nek titulált, amelynek ,utolsó öt perce véres tragédia". ${ }^{126}$

„S nem a szavával, az artikulált beszédével ujjong, mikor az úrnője ruháit magára kapkodja, hanem mozgással, izgatottsággal és ahogy billeg, csetlik-botlik a nagy ruháiban, már leselkedő közelségben vár reá a halál." 127

Akárcsak Sadayakko esetében, itt is a már-már túlzottan realisztikus haláljelenet aratta a legnagyobb sikert a közönség köreiben, amelyben többen valami ősit, természeteset véltek felfedezni, bár a legnagyobb dicséret Hanako esetében is „európaiságának” elismerése volt: „[a]nnak a mozdulatnak a nemessége azonban, amelylyel a gyilkos udvarló kezét urnője kezébe teszi, teljesen nyugati, európai, mintha Duse mozdult volna a Gauthier Margit halálos ágyán”. ${ }^{128}$ Vagyis ,[a]miben elétér, fölöttünk áll és gazdagabb, az a hangok és mozdulatok roppant skálája". ${ }^{129}$ Több kritika kiemeli továbbá a haláljelenet kapcsán a szemeit - valószínüsíthetően a niramit -, amely korábban Rodint is megihlette: ${ }^{130}$

126 Uo.

127 Nádai, 1908. május 3.

128 Erényi, 1908. május 5.

129 Dömötör, 1908. május 24.

130 Ld. bővebben: Doma 2017: 105-110. 
„Egy kicsit sziszeg, egy pár perczig vinnyog, mint egy avarba hulló véres madár, aztán megüvegesednek, borzasztóan elváltoznak szemei és eldül." ${ }^{\text {131 }}$

\section{Halála}

„idegrázó vergődés, amelynek szavát alig halljuk, csak sóhajtását, szemeinek fénye szemünk láttára törik meg [...]."132
„A haldoklási jelenetet vérfagyasztó realizmussal játszsza meg a fiatal japán művésznő. Egyik testrésze a másik után hal el, tagjai rángatóznak, arcza elsápad, lélekzet után kapkod, még egy merev pillantást vet a kö- zönségre, aztán megindul a halálküzdelem, melynek tetőpontja az, hogy Hanakó szájából vércsöppek bukkanak elő és lassan végigfolynak a hal- dokló állán." 133

Hanako sikeres fellépései után 1913 októberében tért vissza Budapestre, ahol ezúttal 4. és 12. között öt estén át három darabbal szerepelt a Budapesti Színház színpadán. A repertoáron a Harakiri, a Teaházban és a már ismert Otake szerepelt, bár Ráskai Ferenc tudósítása szerint a Harakiri és a Teaházban címü produkciókat a publikum már 1908-ban is láthatta, és csak az Otake új müsorszám. ${ }^{134}$ Ez alapján feltételezhető, hogy a másik két darab szerepelhetett a korábbi müsorban, de ez a megállapítás bizonytalan, mivel az Otakét illetően is téved a szerző. A három darab viszont három különböző történettel három eltérő halálmódot nyújtott, amelyekben Hanako „egyformán föl tudott emelkedni a legtisztább müvészet magaslatára," ${ }^{135}$ és meg tudott halni „,[e]lőször csöndesen, szépen, a hogy a láng kialszik, szinte mosolyogva, boldog megkönnyebbüléssel, majd ellenszegülve, vadul küzdve, s végül kinban gyötrelemben rángatódzón". ${ }^{136}$ Ebben az esetben viszont már felmerült az autentikusság kérdése, és $A z$ Ujság munkatársa, Pásztor Árpád ki is mondja, hogy Hanakónak nincsenek japán darabjai. Egyedül a Harakiri rendelkezik japán gyökerekkel a többi csupán ,az európai imprezárió mesterkedése”, aki „,[v]ariétészámot csinált Hanakóból, megbízta, hogy szerezzen be egy húsz-huszonöt

131 Nádai, 1908. május 3.

132 Hanako, Magyarország, 1908. május 3.

133 Egy új Szada-Jakkó, Tolnai Világlap, 1908. március 15.

134 Ráskai, 1913. október 5.

135 Reichenhallerné, 1913. október 12.

${ }^{136}$ Uo. 
perczes apróságot, a melyben minden meglegyen. Japán ének, táncz, bajvivás, szerelem és halál". ${ }^{137}$ Pásztor szerint a Harakiri Chikamatsu Monzaemon (1653-1725), a japán Shakespeare-ként is emlegetett drámaíró munkája, amelynek eredeti címe Banshu Sara-yashiki, és Hanako ennek a münek csak az első felvonását viszi színre. Nem tudni, honnan szerezte információit a szerző, de a Banshu Sarayashiki 番町皿屋敷 valójában egy ismert kaidan 怪談, vagyis szellemtörtént, ${ }^{138}$ amelyből 1741-ben a Toyotake-za számára készített bábelőadást Asada Icchô 浅田一鳥 (?-?), valamint I. Tamenaga Tarobei 為永 太郎兵衛 (?-?), majd 1824-ben, romantikusabb verzióban, I. Nakawa Harusuke 晴助奈河 (1782-?), és III. Segawa Jokō 瀬川如星 (1806-1881) írt belőle kabukidrámát. ${ }^{139}$ Hanako verziójában is egy szolgálólány kijátszása és egy értékes tányér elvesztése körül zajlanak az események, de míg ott a szolgálót ura öli meg azzal, hogy kútba dobja, addig ebben az esetben a Hanako által alakított szolgálólány öngyilkosságot követ el. A darab ugyan - feltételezhetően a nyugati közönségnek szánt ismerősség érdekében - Harakiri címen futott, valójában Hanako „női seppukut” követett el, vagyis átszúrta a nyakát, ami kétségkívül látványosabb és ,véresebb” végkifejletet adott a történetnek. ${ }^{140}$ A Teaházban címü darabnak viszont - amelyben kurtizánt alakít, és egy szamurájt kellene megölnie, de a dolgok balul sülnek el, így a szamuráj egy heves küzdelem után a lányt öli meg ${ }^{141}$ - egyáltalán nincs eredeti japán előzménye, Fuller japanizáló előadása, akárcsak az Otake. „Hanako meghalásaiban csak a nagyszerü produkció marad meg, de a japáni drámák morális alapja nincs meg. Szinház, Európának készült."142

Felmerül a kérdés, hogy miért lett 1913-ban ennyire fontos a darabok eredetisége és Hanako „autentikussága”, amikor haláljeleneteit ugyanúgy csodálták, és színészetét egyesek internacionálisnak vélték. ${ }^{143}$

137 Pásztor, 1913. október 7.

138 A történet a szépséges Okiku szolgálólány igazságtalan haláláról és szellemként való visszatéréséről szól. Ura, a szamuráj Aoyama szeretné, ha a lány a szeretőjévé válna, de ő mindig visszautasítja. Hogy megleckéztesse Okikut rábíz tíz értékes tányért, amelyből egyet titokban elcsen. A lány hiába számolja újra és újra, csak kilencet talál. Végül bevallja Aoyamának, hogy elveszített egy tányért, a férfi viszont hajlandó megbocsátani, ha a lány a szeretője lesz. Ezt Okiku ismét visszautasítja, mire a férfi bedobja őt egy kútba. Halála után Okiku addig jár vissza kísérteni, míg meg nem találják a tizedik tányért.

140 Pásztor, 1913. október 7.

141 A cselekményröl bővebben: Reichenhallerné, 1913. október 12.

142 Pásztor, 1913. október 7.

143 Hanako, A Hét, 1913. október 12. 
Az internacionalitás kérdése valószínüleg ugyanúgy a haláljelenethez kapcsolódott, és a magyar közönség is ugyanazt az „,egyetemességet” látta meg Hanako játékában, amelyet korábban Fuller, Duncan, St. Denis vagy Rodin. Emellett viszont Fuller darabjai 1913-ra mintha elvesztették volna eredetiségük látszatát, és mint korábban említettem, egyszerünek és müvinek tüntek, szemben például Sadayakkóék korábbi repertoárjával, amely minden esetben valós kabukidarabokból építkezett. Elmondható tehát, hogy a magyar közönség esetében Hanako előadásai már kezdtek túl ismerőssé válni, és a haláljelenetek nélkül inkább komikusak voltak, nem igazán értek el hatást, a produkciók inkább „emberi szenzációt" ${ }^{\text {"144 }}$ kínáltak, mint müvészit. Ezzel ellentétben a Kawakami-társulat a valódi kabukidaraboknak köszönhetően meg tudta örizni idegenségét.

A magyar kritikusok között ez a felfedezés, a hitelesség kérdésének az elvesztése, Szász Zoltán esetében éri el a csúcspontot, aki durva, becsmérlő és kirekesztő kritikával illeti Hanakót azzal, hogy cirkuszi ,athlétikával edzett törpé"-hez hasonlítja. Véleménye szerint nincs benne magasabb müvésziség, sokszor dicsért kecses mozgása inkább alsóbbrendü és állatias. Cikke végén pedig a darwini elméletre hivatkozva a japánokat közelebb állóknak tartja a majmokhoz, amelyre jó példa Hanako és társulata. ${ }^{145}$

Sadayakkóról budapesti fellépése után évekkel később is jelentek meg rövidebb cikkek. Hanakóról ez nem mondható el, mivel hazájában soha nem lépett színpadra, viszont mindkét színésznőről olvasható volt két „leleplező” cikk. Az első 1911-ben Pásztor Árpád tollából, aki a Vasárnapi Ujságnak számolt be tokiói látogatásáról és az ottani színházigazgatókkal való találkozásáról. Ugyanebben a szövegben is számos életrajzi pontatlanság van a két színésznőt illetően, az viszont egyértelmüen kiderül, hogy ők valójában csak nyugaton léteznek. Főként igaz ez Hanakóra, akiről még annyit sem tudnak hazájában, mint Sadayakkóról, aki Japánban is ért el sikereket Kawakami Otojirōval. A riportban az is elhangzik, hogy a szigetországban nincsenek színésznők, így Sadayakko és Hanako nem is képviselhetik a hagyományos japán színház értékeit. ${ }^{146} \mathrm{Az}$ a gondolat pedig, hogy nők nem képviselhetik a hagyományos japán színház értékeit, összecseng Craig Sadayakkóval kapcsolatos megállapításával, amely szerint jobb lenne, ha nem szerepelnének

144 Hanako, Világ, 1913. október 7.

145 Szász, 1913. október 14.

146 Pásztor, 1911. március 26. 
nők a japán színpadon, mert nem ez a színjáték ősi és természetes formája. ${ }^{147}$ (Természetesen a kabukiról abból a szempontból sosem beszélnek, hogy eredetileg nők táncaiból alakult ki, tehát a női színjátszásnak abszolút van létjogosultsága Japánban.) Hozzá kell tenni azonban, hogy a riport ellenére Sadayakkót továbbra is úgy fogják emlegetni, mint addig, és Hanakónak a második budapesti szereplésére sem volt hatással a megjelent cikk, hiszen továbbra is a tokiói Császári Színház tagjaként tüntették fel.

Érdekes adalék ellenben Pásztor másik, szintén leleplezőnek szánt írása 1913. októberéből, vagyis Hanako második vendégjátékának idejéből. Itt is megerósítést nyer, amit már néhányan a színpadon is látni vélnek, hogy amit Európában látunk, annak semmi köze a hagyományos japán színházhoz (jelen esetben a kabukihoz), de jelentős vagyont lehet szerezni bármiféle japanizáló elöadással, hiszen a nyugati közönség nagy eséllyel még sosem látott autentikus japán színházat. Figyelemre méltó, hogy itt valós életrajzi adatok jelennek meg Sadayakkóról és Kawakami Otojirōól, a soshi és shinpa mozgalomról, ${ }^{148}$ emellett pedig Hanako is megszólal a cikkben, és megvallja, hogy produkcióikban minden európai. ${ }^{149}$

„Minden úgy történik, a hogy az európaiak akarják. Egy kis jelenetben mindent meg kell csinálnom. Az imprezárió kívánsága parancs. Majdnem sírtam, mikor Londonban a Savoy-Theatre-ben a japán hangszer, a djorori nélkül kellett fellépnem. De kellett! Az imprezárió akarta. A müsort is szerinte állítom össze. Csak egyszer szeretnék Európában valódi japán színészetet bemutatni! De ki tudja, hogy sikerül-e? Londonban ott van minden hangszerem, de nem játszhatom rajta, senki sem érti." 150

Amennyiben elfogadjuk e nyilatkozat hitelességét, az erős áldozati felhangokkal bíró szöveg ismét visszavezet Hanako önállóságának kérdéséhez. Ez alapján Hanakónak nem volt semmiféle függetlensége, és valóban csak Fuller bábjaként létezett, kénytelen volt végrehajtani minden utasítást. Nem tudható azonban, hogy Hanakónak ez a fajta megnyilvánulása mennyiben marketingfogás, hogy ugyanazt az áldozatot látjuk megjelenni az életben, mint színpadi szerepei esetében. Ráadásul a teljes önállótlanságnak ellentmond a Harakiri

147 Vö. Craig 2014.

148 Ld. bővebben: Doma 2018.

149 Pásztor ,1913. október 7.

150 Uo. 
címü produkció. Mivel a többi előadásukkal szemben ennek egy népszerü japán szellemtörténet és báb-, illetve kabukidarab az alapja, feltételezhető, hogy nem Fuller ötlete volt a színpadra állítás. Természetesen az alaptörténet, vagyis a „harakiri”-jelenet és cím módosítása már arra utalhat, hogy „nyugati” szemszögből közelítenek az alapanyaghoz, de ez ugyanúgy lehetett közös munka eredménye is. A nyilatkozat hitelességét azonban az is megkérdőjelezi, hogy még reklámfogás miatt sem szerencsés „,bevallani” a közöségnek, hogy minden európai, ha emellett a színpadon arra törekednek, hogy „valódi” japán előadásokként adják el a produkcióikat,

Mindenesetre 1913-ra úgy tünik, hogy a magyar közönséget már kevésbé elégítette ki a csupán japán klisékre támaszkodó, de egyébként semmiféle autentikusságot nem tartalmazó előadások halmaza. Ennek fényében más megvilágításba kerül az az eset is, amikor Hanako a feltünés kedvéért világító izzókkal a ruháján jelent meg a közönség elött. Ezen a ponton már teljesen egyértelmüvé vált, hogy Hanako és Fuller kizárólag a látványos sikerekre építenek, ha kell, mellőzve a japán színház minden hagyományos vonását. A Kawakami-társulatnak ellenben interkulturális előadásaikkal végig sikerült megőriznie a közönség szemében az eredetiség látszatát, míg Hanako japanizáló előadásaiból - a nirami ellenére is - mindenfajta vágyott autentikusság kiveszett.

\section{Elsődleges források}

„A Beöthy-Liptai ügy”. Hazánk, 1902. április 6.

„A gésa és a lovag”. Budapesti Napló, 1900. december 30.

„A japán velencei kalmár”. Pesti Hírlap, 1902. február 27.

„A japáni dráma és szinpad”. Vasárnapi Ujság, 1902. március 2.

„A japáni társaság s a Nemzeti Szinhaz igazgatója”. Pesti Napló, 1902. február 27.

„A japánok”. Vasárnapi Ujság, 1904. március 6.

„A szinhaz Japánban”. Budapesti Hirlap, 1900. március 9.

Ady Endre: „Beöthy László japánjai”. Nagyváradi Napló, 1902. március 6.

„Arbré jeles társasága”. Magyar Polgár, 1885. július 25.

„Beöthy László - magánvállalata”. Magyarország, 1902. február 26.

„Beöthy László magánvállalata”. Hazánk, 1902. február 27.

„Beöthy László - magánvállalata”. Magyarország, 1902. február 27.

„Beöthy László és az Uránia”. Alkotmány, 1902. február 26.

„Beöthy László és az Uránia”. Alkotmány, 1902. február 27.

„Beöthy László magánvállalata”. Pesti Hirlap, 1902. február 27.

Dömötör István: „Hanako”. Uj Idők, 1908. május 24. 
„Egy japán primadonna”. Pesti Hirlap, 1900. szeptember 13.

„Egy új Szada-Jakkó”. Tolnai Világlap, 1908. március 15.

Emma: „Saison”. A Hét, 1902. december 7.

Erényi Nándor: „Sada Yacco Londonban”. Budapesti Napló, 1902. február 19.

Erényi Nándor: „Hanako”. Pesti Napló, 1908. május 5.

„Hanako”. Pesti Hírlap, 1906. október 22.

„Hanako”. Pesti Napló, 1906. november 1.

„Hanako”. Az Ujság, 1908. március 8.

„Hanako”. Budapesti Hírlap, 1908. május 3.

„Hanako”. Magyarország, 1908. május 3.

„Hanako”. Az Ujság, 1908. május 4.

„Hanako”. Világ, 1913. október 7.

„Hanako”. A Hét, 1913. október 12.

„Hanako Berlinben”. Népszava, 1908. február 28.

„Japáni darab a Vigszinházban”. Pesti Hírlap, 1900. december 27.

„Japáni sárkányok”. Vadász és Versenylap, 1868. január 30.

„Japáni szinészek”. Pesti Hírlap, 1900. június 1.

„Japáni szinészek”. Pesti Hírlap, 1900. június 2.

„Japáni szinészek”. Vasárnapi Ujság, 1902. február 23.

Kosztolányi Dezső 1966. Idegen költök. Összegyüjtött müfordítások. Budapest: Szépirodalmi Kiadó.

„Látogatás Szada Yakkónál”. Vasárnapi Ujság, 1902. március 9.

oh: „Japáni élet a szinpadon”. Budapesti Hírlap, 1902. február 25.

Nádai Pál: „Hanako”. A Hét, 1908. május 3.

Pásztor Árpád: „A japán szinház”. Vasárnapi Ujság, 1911. március 26.

Pásztor Árpád: „Hanako és a japán szinház”. Az Ujság, 1913. október 7.

Pásztor Mihály: „Pálmay Ilka, mint Pillangó kisasszony”. Vasárnapi Ujság, 1901. október 27.

Ráskai Ferenc: „Hanako”. Pesti Hírlap, 1913. október 5.

Reichenhallerné Petheö Irén: „Hanako”. Budapesti Hírlap, 1913. október 12.

Réthi Lajos: „A japáni »sárkány-társaság« mutatványai”. Vasárnapi Ujság, 1868. január 19.

„Sada Yacco”. Pesti Hírlap, 1900. augusztus 5.

„Sada Yacco, a »japán Duse«”. Budapesti Napló, 1900. szeptember 13.

„Sada Yacco a japán primadonna a Vigszinházban”. Pesti Hirlap, 1900. szeptember 26.

„Sada Yacco kondoleál”. Hazánk, 1902. április 12.

„Sada Yacco az Urániában”. Pesti Hírlap, 1902. február 22.

„Saday Yacco: Életemből”. Budapesti Napló, 1900. szeptember 19.

Sámi Lajos: „Japán hajdan és most - Szinészek és szinházak”. Vasárnapi Ujság, 1875. november 14.

„Szada Yakko és társulata Budapesten”. Vasárnapi Ujság, 1902. március 2.

Szász Zoltán: „Hanako s a többi japáni”. Pesti Hírlap, 1913. október 14.

Vasárnapi Ujság, 1877. április 29.

Vasárnapi Ujság, 1886. december 19.

Vasárnapi Ujság, 1897. október 24. 


\section{Felhasznált másodlagos szakirodalom}

Anderson, Joseph L. 2011. Enter a Samurai: Kawakami Otojiro and Japanese Theatre in the West. Tucson: Wheatmark.

Belitska-Scholtz Hedvig - Rajnai Edit - Somorjai Olga (szerk.) 2005. Színháztörténeti Képeskönyv. Budapest: Osiris Kiadó, 164-167.

Bitterli, Urs 1982. „,Vadak” és ,civilizáltak”. Budapest: Gondolat Kiadó.

Bozó Péter 2013. Operett Magyarországon, 1860-1958 forráskatalógus. http://www.zti.hu/ mza/docs/Egyeb_publikaciok/Operett-forraskatalogus_BozoPeter.pdf (utolsó letöltés: 2019.08.18.).

Bozó Péter 2016. „A mikádó halállistája, avagy a performativitás mint szövegkritikai probléma”. Filológiai Közlöny 62/4: 350-366.

Bögös László 1991. „Régi századok magyarjai Vietnamban”. Ezredvég 1/6. http://ezredveg. vasaros.com/html/1991_06/91062.html (utolsó letöltés: 2019.08.18.).

Bradley, Ian 2016. The Complete Annotated Gilbert \& Sullivan: 20th Anniversary Edition. Oxford: Oxford University Press.

Burlingame, H. J. 1895. History Of Magic And Magicians. https://archive.org/details/ HistoryOfMagicAndMagicians/page/n1 (utolsó letöltés: 2019.08.19.).

Craig, Edward G. 2014. „Sada Yacco”. (Ford. Doma Petra.) Theatron 13/3: 3-5.

Dénes Mirjam 2012a. „A pillangó-effektus, avagy a komédiából tragédiává lett japán a magyar színpadon". Színház, http://szinhaz.net/2012/05/30/denes-mirjam-a-pillango-effektusavagy-a-komediabol-tragediava-lett-japan-a-magyar-szinpadon/ (utolsó letöltés: 2019.08.18.).

Dénes Mirjam 2012b. „Japonizáló díszletek, jelmezek és a tradicionális japán művészet kapcsolatai”. In: Takó Ferenc (szerk.) „Közel, s Távol” II. - Az Eötvös Collegium Orientalisztika Mühely éves konferenciáinak elöadásaiból. Budapest: Eötvös Collegium, 306-326.

Dénes Mirjam 2013. „Cio-Cio-San szobái - A japanizmus alakváltozásai a Pillangókisasszony tükrében". Artmagazin 1: 44-49.

Dénes Mirjam 2017a. „A japonizmus árnyalatai - Japán kulturális és művészeti recepciója Magyarországon". In: Dénes Mirjam - Fajcsák Györgyi - Marosvölgyi Gábor Fertőszögi Péter (szerk.) Japonizmus a magyar müvészetben. Budapest: Kovács Gábor Múvészeti Alapítvány, 111-211.

Dénes Mirjam 2017b. „Fel kell adni a centrum-periféria megközelítést”. Magyar Múzeumok, https://archiv.magyarmuzeumok.hu/tema/3931_fel_kell_adni_a_centrum-periferia_ megkozelitest (utolsó letöltés: 2019.10.19.).

Dénes Mirjam 2019. Japán mint jelenség és mint téma a Monarchia színpadjain, három felvonásban. Kézirat.

Dénes Mirjam - Sebestyén Ágnes Anna 2016. „Egy magyar utazó Japán-olvasata a századfordulón: Bozóky Dezső fotográfiái”. In: Doma Petra - Takó Ferenc (szerk.) „Közel, s Távol” V. - Az Eötvös Collegium Oreintalisztika Mühely éves konferenciájának elöadásaiból 2015. Budapest: Eötvös Collegium, 11-34. 
Doma Petra 2011. „A japán-orosz háború a magyar köztudatban”. In: Takó Ferenc (szerk.) „Közel, s Távol” - Az Eötvös Collegium Orientalisztika Mühely éves konferenciájának elöadásaiból, 2009-2010. Budapest: Eötvös Collegium, 143-153.

Doma Petra 2013. „Az Idegen vonzásában - Sadayakko és Matsui Sumako színészi (ön)definíciója a nyugati és a japán színházművészetben”. Theatron 12/4: 74-91.

Doma Petra 2017. „A Halál arca - Hanako megjelenése az európai színpadon”. In: Doma Petra (szerk.) SZITU Kötet 2016. Budapest: ELTE Eötvös József Collegium, 95-114.

Doma Petra 2018. „A hagyományos kabuki és shinpa háborúja a 19-20. század fordulóján”. Távol-keleti Tanulmányok 9/2: 133-150.

Doma Petra 2019. „Kavakami Otodzsiró: A szeigeki létrehozója”. In: Farkas Ildikó Sági Attila (szerk.) Kortárs Japanológia III. Budapest: Károli Gáspár Református Egyetem, L'Harmattan Kiadó, 239-258.

Downer, Lesley 2003. Madame Sadayakko. Polmont: Review.

Farkas Ildikó 2009. „Japán megjelenése Magyarországon a XIX-XX. század fordulóján”. In: Farkas Ildikó - Szerdahelyi István - Umemura Yuko - Wintermantel Péter (szerk.) Tanulmányok a magyar-japán kapcsolatok történetéböl. Budapest: ELTE Eötvös Kiadó, 63-88.

Fukai, Akiko „Japonism in Fashion”. (Ford. Amanda Mayer Stinchecum.) kci.or.jp https://www.kci.or.jp/research/dresstudy/pdf/e_Fukai_Japonism_in_Fashion.pdf (utolsó letöltés: 2019.08.18.).

Gajdó Tamás (szerk.) 2001. Magyar Szinháztörténet II. Budapest: Magyar Könyvklub - Országos Színháztörténeti Múzeum és Intézet.

Gajdó Tamás 2019. Színházi előadások a „bájos, kedves, elragadó” Urániában. Kézirat.

Gál György Sándor - Somogyi Vilmos 1960. Operettek könyve. Budapest: Zenemükiadó Vállalat.

Gellér Katalin 2017. „Japán és a Hold között”. In: Dénes Mirjam - Fajcsák Györgyi Marosvölgyi Gábor - Fertőszögi Péter (szerk.) Japonizmus a magyar müvészetben. Budapest: Kovács Gábor Müvészeti Alapítvány, 7-110.

Jacobs, Angelika 2009. „A »vadon« mint a nyugati civilizáció vágyott tere. Az egzotizmus kritikájáról Peter Altenberg Ashantee és Robert Müller Trópusok címü müvében”. (Ford.: Szabó Judit.) In: Csúri Károly - Mihály Csilla - Szabó Judit (szerk.) Határátlépések. Budapest: Gondolat, 241-260.

Kano, Ayako 2001. Acting Like a Woman in Modern Japan. New York: Palgrave.

Kawaguchi, Yoko 2016. Authentic Japanese Gardens - Creating Japanese Design and Detail in the Western Garden. IMM Lifestyle Books.

Koósz István 2017a. „Japáni sárkányok 1. rész - Japán akrobata csoport vendégjátéka 1868-ban a Budai Népszínházban”. McTEKA 10.3. http://mcteka.shp.hu/hpc/web. php?a=mcteka\&o=100303_koosz_japs_1_6yxw (utolsó letöltés: 2019.08.19.).

Koósz István 2017b. „Japáni sárkányok 2. rész - Japán akrobata csoport vendégjátéka 1868-ban a Budai Népszínházban”. McTEKA 10.4. http://mcteka.shp.hu/hpc/web. php?a=mcteka\&o=100401_koosz_2_3kPC (utolsó letöltés: 2019.08.19.).

Koósz István (szerk.) 2019. A japán színház Magyarországon-Bibliográfia. Budapest. http://hdl.handle.net/10831/42789 (utolsó letöltés: 2019.08.18.). 
Kosztolányi Dezső 1966. Idegen költők. Összegyüjtött müforditások. Budapest: Szépirodalmi Kiadó.

Molnár Gál Péter 2001. A pesti mulatók. Budapest: Helikon.

Moon, Krystyn N. 2009. „Paper Butterflies: Japanese Acrobats in Mid-Nineteenth-Century New England". In: Monica Chiu (ed.) Asian Americans in New England. New Hampshire: University of New Hampshire Press, 66-90.

Penley, Nicole 2003. „Japanese Orientalism in Britain: As Seen through the Eyes of W. S. Gilbert and Arthur Sullivan in their opera, The Mikado". Fairmount Folio: Journal of History 5: 52-64.

Roberts, Jeremy 2009. Japanese Mythology A to Z. Chelsea House.

Rothfels, Nigel 2002. Savages and Beasts - The Birth of the Modern Zoo. Baltimore \& London: The Johns Hopkins University Press.

Savarese, Nicola - Flower, Richard 1988. „A Portrait of Hanako”. Asian Theatre Journal. 5/1: 63-75.

Sawada Suketrō 澤田助太郎 1996. Rodan to Hanako ロダンと花子 [Rodin és Hanako]. Tokyo: Chūnichi shubbansha 中日出版社.

Sarayashiki. https://www.kabuki21.com/banshu_sarayashiki.php (utolsó letöltés: 2019.08.19.).

Staud Géza 1999. Az orientalizmus a magyar romantikában. Budapest: Terebess Kiadó. https://terebess.hu/keletkultinfo/staud.html (utolsó letöltés: 2019.08.18.).

Szerdahelyi G. István 1996. „Az orosz-japán háború és a magyar politikai közvélemény”. In: Yamaji Masanori (szerk.) Japán-kutatás Magyarországon. Budapest: ELTE Japanese Studies, 33-55.

Szerdahelyi István 2009. „Az Osztrák Magyar Monarchia és a Japán Császárság között 1869. október 18-án kötött kereskedelmi szerződés". In: Farkas Ildikó - Szerdahelyi István - Umemura Yuko - Wintermantel Péter (szerk.) Tanulmányok a magyarjapán kapcsolatok történetéböl. Budapest: ELTE Eötvös Kiadó, 27-43.

Tarjányi Eszter 2016. „Regénybe rejtett operett - Kosztolányi Pacsirtája - a lélektani regény és a népszerü mủfaj szimbiózisa”. Partitúra 11/2: 31-50.

Tóth Gergely 2018. Japán-magyar kapcsolattörténet 1869-1913. Budapest: Gondolat.

Traubner, Richard 2003. Operetta. London\&New York: Routledge. 